\title{
DAMPAK PROGRAM UPSUS (UPAYA KHUSUS) TERHADAP PRODUKTIVITAS PADI DI SUBAK SANGEH KECAMATAN ABIANSEMAL KABUPATEN BADUNG
}

\author{
Impact of Spesial effort on rice productivity at Subak Sangeh, Subdistrict of \\ Abiansemal, Badung Regency
}

\section{Gusti Ngurah Abung Mataliana, Made Antara, Ni Wayan Sri Astiti}

Program Studi Magister Agribisnis, Fakultas Pertanian, Universitas Udayana, Bali, Indonesia

E-mail: abungmataliana23@gmail.com

\begin{abstract}
Spesial effort on rice production is an effort has been proposed by agriculture ministry in order to improve the productivity of rice, corn and soybeans. This study aims to find out the performance of Spesial effort on rice production program, to find out the impact of Spesial effort on rice production program on padddy productivity at Subak Sangeh, subdistrict of Abiansemal, Badung regency. The research method used quantitative method based on farming business analysis and t test. Primary data was collected by using interview method to 78 farmers with data collection in the form of production cost and production area.The results showed that the cost of rice farming business at Subak Sangeh in implementing the Spesial effort on rice production Program amounted to $R p$ 7.229.116/ hectare per planting season. Farmers income at Subak Sangeh was Rp 30,970,000 / hectare per planting season. So the income of rice farmers at Subak Sangeh in applying the Upsus Program Rp 23.740.884 I ha / $\mathrm{mt}$, and the $R / C$ Ratio of 4.28. The Spesial effort on rice production program can also increase the productivity of paddy, from 6.19 tons / hectare up to 8.15 tons / hectare increased by $24.05 \%$. The t test analysis showed significant value of 0.000 which is smaller than 0.01 its shows there is significant difference of productivity of rice farming at Subak Sangeh. This also means that the implementation of the Spesial effort on rice production Program is very influential to improve the productivity of rice farming at Subak Sangeh. Therefore, the Spesial effort on rice production Program is better to be optimezed in order to improve productivity of paddy.
\end{abstract}

Keywords: impact, special effort, productivity, rice plant

\begin{abstract}
ABSTRAK
Upaya khusus pada produksi padi adalah upaya yang telah diusulkan oleh kementerian pertanian untuk meningkatkan produktivitas beras, jagung dan kedelai. Penelitian ini bertujuan untuk mengetahui kinerja usaha Khusus pada program produksi padi, untuk mengetahui dampak dari upaya Khusus pada program produksi padi terhadap produktivitas paddy di Subak Sangeh, kecamatan Abiansemal, Kabupaten Badung. Metode penelitian menggunakan metode kuantitatif berdasarkan analisis bisnis pertanian dan uji t. Data primer dikumpulkan dengan menggunakan metode wawancara kepada 78 petani dengan pengumpulan data dalam bentuk biaya produksi dan area produksi. Hasil penelitian menunjukkan bahwa biaya usaha usahatani padi di Subak Sangeh dalam melaksanakan usaha Khusus pada program produksi beras sebesar Rp 7,229 .116 / hektar per musim tanam. Pendapatan petani di Subak Sangeh adalah Rp 30.970.000 / hektar per musim tanam. Jadi penghasilan petani padi di Subak Sangeh dalam menerapkan Program Upsus Rp 23.740.884 / ha / mt, dan R / C Ratio 4,28. Upaya khusus pada program produksi padi juga dapat meningkatkan produktivitas padi, dari 6,19 ton / hektar hingga 8,15 ton / hektar meningkat 24,05\%. Analisis uji t menunjukkan nilai signifikan 0,000 yang lebih kecil dari 0,01 menunjukkan ada perbedaan produktivitas padi yang signifikan di Subak Sangeh. Ini juga berarti bahwa pelaksanaan upaya Khusus pada program produksi padi sangat berpengaruh untuk meningkatkan produktivitas usahatani padi di Subak Sangeh. Oleh karena itu, upaya Khusus Program Produksi Padi lebih baik untuk dioptimalkan guna meningkatkan produktivitas padi.
\end{abstract}

Kata kunci: dampak, upaya khusus, produktivitas, tanaman padi 


\section{PENDAHULUAN}

\section{Latar Belakang}

Sektor pertanian merupakan salah satu sektor utama sebagai penghasil pangan. Pertanian menjadi sangat penting karena mempunyai kontribusi dalam pencapaian tujuan pembangunan perekonomian nasional karena Indonesia merupakan negara agraris yang sebagian besar masyarakat indonesia adalah petani. Dengan demikian sektor pertanian harus tetap dijaga keberlangsungannya agar dapat membangun sektor pertanian yang berkelanjutan (BPS, 2010).

Pembangunan pertanian adalah usaha untuk meningkatkan produksi pertanian baik kuantitas maupun kualitas. Pembangunan adalah penciptaan sistem dan tata nilai yang lebih baik hingga terjadi keadilan dan tingkat kesejahteraan yang tinggi. Sistem tersebut harus berdaya saing, berkerakyatan, berkelanjutan, dan desentralistik. Program pembangunan pertanian pada hakikatnya adalah serangkaian upaya untuk memfasilitasi, melayani, dan mendorong berkembangnya sistem pertanian dan usaha-usaha pertanian yang berdaya saing, berkerakyatan, dan berkelanjutan (Mosher,1968).

Menghadapi kendala dan tantangan yang ada, kabinet Kerja dan kementrian pertanian telah menetapkan pencapaian swasembada berkelanjutan padi dan jagung serta swasembada kedelai yang harus dicapai dalam waktu tiga tahun yaitu tahun 2015 sampai dengan tahun 2017 yang dinamakan dengan program Upaya Khusus peningkatan produksi padi jagung dan kedelai (UPSUS PAJALE). Untuk pencapaian swasembada berkelanjutan padi dan jagung serta swasembada kedelai, penyuluh, mahasiswa dan bintara Pembina desa (babinsa) menjadi unsur penting dalam menggerakkan para petani pelaku utama untuk dapat menerapkan teknologi. Penyuluh, mahasiswa dan babinsa merupakan salah satu faktor penggerak bagi para petani (pelaku utama) dan dapat berperan aktif sebagai komunikator, fasilitator, advisor, motivator, edukator, organisator dan dinamisator dalam rangka terlaksananya kegiatan upaya khusus peningkatan produksi padi, jagung dan kedelai dalam pencapaian swasembada berkelanjutan padi dan jagung serta swasembada kedelai.

Melihat produktivitas padi di Kecamatan Abiansemal yang masih rendah, pemerintah Kabupaten Badung melaksanakan Program Upsus untuk meningkatan produktivitas padi di Subak Sangeh. Program Upsus telah dilaksanakan dalam kurun waktu tiga tahun, maka perlu dilakukan suatu penelitian mengenai dampak Program Upsus padi di Subak Sangeh.

\section{Rumusan Masalah}

Berdasarkan uraian latar belakang di atas maka masalah dapat dirumuskan sebagai berikut.

1. Bagaimana keragaan Program Upsus padi di Subak Sangeh yang dilihat dari pendapatan petani?

2. Bagaimana dampak Program Upsus di Subak Sangeh terhadap produktivitas padi ?

3. Apa kendala-kendala yang dihadapi oleh petani padi di Subak Sangeh?

\section{Tujuan Penelitian}

Berkaitan dengan rumusan masalah di atas maka tujuan penelitian untuk mengetahui hal-hal antara lain sebagai berikut.

1. Mengetahui keragaan Program Upsus padi di Subak Sangeh yang dilihat dari pendapatan petani.

2. Mengetahui dampak Program Upsus di Subak Sangeh terhadap produktivitas padi.

3. Mengetahui kendala-kendala yang dihadapi oleh petani padi di Subak Sangeh.

\section{Kerangka Konsep Penelitian}

Ketahanan pangan di Indonesia sangat tergantung dari ketersediaan stok beras yang bisa disediakan secara nasional. Khomsam (2003), kedaulatan pangan menjadi harga mati sebagai cita-cita dalam rangka mewujudkan mimpi kemandirian bangsa dan negara dalam bidang pangan. Dalam menghadapi kendala dan tantangan yang ada, Kabinet Kerja telah menetapkan pencapaian swasembada berkelanjutan padi dan jagung serta swasembada kedelai yang harus dicapai dalam waktu tiga tahun. Adapun target produksi yang harus dicapai pada tahun 2015 adalah produksi padi sebesar 73,40 juta ton dengan pertumbuhan $2,21 \%$ jagung sebesar 20,33 juta ton dengan pertumbuhan $5,57 \%$ dan kedelai sebesar 1,27 juta ton dengan pertumbuhan 26,47\%. Subak Sangeh telah menerapkan Program Upsus, maka perlu dilakukan suatu penelitian mengenai dampak Program Upsus padi di Subak Sangeh.

\section{METODE PENELITIAN}

\section{Rancangan Penelitian}

Penelitian mengenai dampak Program Upsus padi di Subak Sangeh, Desa Sangeh, Kecamatan Abiansemal, Kabupaten Badung. Analisis yang digunakan adalah analisis pendekatan usahatani. Hal ini bertujuan untuk mengetahui seberapa besar pendapatan petani padi dalam menerapkan Program 
Upsus padi serta penelitian ini juga menggunakan analisis uji- $t$. Uji- $t$ bertujuan untuk melihat nilai tengah produktivitas padi sebelum menerapkan Program Upsus berbeda secara nyata atau tidak dengan nilai tengah produktivitas padi setelah menerapkan Program Upsus di Subak Sangeh, Desa Sangeh, Kecamatan Abiansemal, Kabupaten Badung.

\section{Lokasi dan Waktu Penelitian}

Penelitian akan dilaksanakan di Subak Sangeh, Desa Sangeh, Kecamatan Abiansemal, Kabupaten Badung. Pelaksanaan penelitian dilaksanakan pada Bulan Februari 2017 sampai dengan April 2017.

\section{Jenis Data dan Sumber Data}

Dalam penelitian ini data yang dikumpulkan mencakup data kualitatif dan kuantitatif. Menurut Kuncoro (2003), Data kuantitatif yang dicari dalam penelitian ini meliputi jumlah produksi, harga jual, biaya produksi seperti benih, pupuk, pestisida, tenaga kerja. Dan kuantitatif lainnya adalah karakteristik petani meliputi: umur, jumlah anggota keluarga, luas penguasaan lahan. Data kualitatif yang dikumpulkan dalam penelitian ini meliputi gambaran umum usahatani padi, kendala yang dihadapi petani dalam menjalankan usahatani, tingkat pendidikan petani, dan pekerjaan petani.

\section{Sumber Data}

Berdasarkan sumbernya, data terdiri atas data primer dan data sekunder. Data primer adalah data yang diperoleh secara langsung dari sumber pertama atau bersumber dari para petani (Singarimbum dan Effendi,1989). Data primer yang dipergunakan dalam penelitian ini meliputi identitas umum petani sampel, produksi dan biaya, kendala-kendala dalam proses produksi dan penjualannya. Data sekunder diperoleh dari lembaga atau instansi yang terkait dengan penelitian.

\section{Populasi dan Sampel Penelitian}

Populasi adalah keseluruhan elemen atau unsur yang akan diteliti Gulo (2000). Populasi dalam penelitian ini adalah petani padi menerapkan Program Upsus yang berada di lingkungan Subak Sangeh yang berjumlah 328 orang petani.

Teknik pengambilan sampel dalam penelitian ini dengan menggunakan metode Proportionale Random Sampling Menurut Arikunto (2008), penentuan pengambilan sampel sebagai berikut: apabila kurang dari 100 lebih baik sampel diambil semuanya. Jika jumlah subyeknya besar dapat diambil antara $10-15 \%$ atau 20-55 \% atau lebih tergantung dari : (1) kemampuan peneliti dilihat dari waktu, dan tenaga. (2) luasnya wilayah pengamatan dan (3) besar kecilnya resiko. Untuk pedoman umum dapat dilaksanakan bahwa bila populasi di bawah 100 orang, maka dapat digunakan sampel $50 \%$, dan jika di atas 100 orang dilakukan $10-15 \%$ atau 20-55 \%. Jumlah sampel dalam penelitan ini ditentukan dengan metode slovin dengan tingkat eror $10 \%$. Dari jumlah populasi sebanyak 328 orang maka respondennya yaitu 78 orang. Dengan demikian, jumlah responden dalam penelitian ini berjumlah 78 orang yang terbagi dalam lima munduk. Munduk. Munduk Mumbul sebanyak 18 orang, Munduk Jemeng sebanyak 14 orang, Munduk Jambangan sebanyak 12 orang, Munduk Wasi sebanyak 14 orang, dan Munduk Tenguli sebanyak 20 orang.

\section{Metode Analisis Data}

Untuk menjawab rumusan masalah dalam penelitian ini akan digunakan beberapa analisis seperti berikut:

1. Untuk menjawab rumusan masalah yang pertama mengenai keragaan Program Upsus di Subak Sangeh akan digunakan analisis deskriptif kuantitatif dengan pendekatan analisis usahatani.

2. Untuk menjawab rumusan masalah yang kedua mengenai dampak Program Upsus akan dianalisis secara deskriptif kuantitatif dengan uji t. Dalam penelitan ini uji $t$ digunakan untuk melihat perbedaan produktivitas padi di Subak Sangeh sebelum menerapkan Program Upsus dengan setelah menerapkan Program Upsus. Dependent sample t-test atau sering diistilakan dengan Paired Sampel t-Test, adalah jenis uji statistika yang bertujuan untuk membandingkan rata-rata dua grup yang saling berpasangan. Sampel berpasangan dapat diartikan sebagai sebuah sampel dengan subjek yang sama namun mengalami dua perlakuan atau pengukuran yang berbeda, yaitu pengukuran sebelum dan sesudah dilakukan sebuah treatment.

3. Untuk menjawab rumusan masalah yang ketiga mengenai kendala-kendala dalam usahatani padi dengan menerapkan Program Upsus akan dianalisis secara deskriptif kualitatif, dengan melakukan wawancara mendalam dengan petani

\section{HASIL DAN PEMBAHASAN}

\section{Keragaan Program Upsus Padi di Subak Sangeh}

Teknik budidaya padi yang dilakukan oleh petani yang menerapkan Program Upsus maupun sebelum menerapkan Program Upsus pada dasarnya sama, di mana proses produksi keduanya melalui beberapa tahapan seperti, persiapan lahan, persemaian, penanaman, penyiangan, pemupukan, penyemprotan, dan pemanenan. Namun, pada masing-masing tahapan terdapat beberapa aktivitas yang dimodifikasi sesuai aturan yang telah ditetapkan dalam Program Upsus. 
a) Persiapan Lahan

Petani padi di Subak Sangeh membajak sawahnya dengan menggunakan traktor, ratarata biaya sewa traktor termasuk upah borongan pekerjanya dan bahan bakar solar adalah sebesar Rp18.000/are. Selanjutnya, lahan sawah yang sudah dibajak diratakan menggunakan sorongan, kemudian digenangi melalui saluran air (kemalir) selama tiga hari. Proses terakhir adalah pengeringan sawah dan membuat jarak tanam padi menggunakan caplak.

b) Persemaian

Membuat persemaian merupakan aktivitas yang berjalan beriringan dengan aktivitas persiapan lahan. Luas tempat persemaian disesuaikan dengan jumlah lahan dan jumlah bibit. Jumlah bibit yang optimal untuk ditanam sesuai ketentuan pada Program Upsus adalah sebanyak $18 \mathrm{~kg} / \mathrm{ha}$

c) Penanaman

Salah satu komponen teknologi pilihan dalam Program Upsus adalah menerapkan sistem tanam jajar legowo. Tenaga kerja untuk penanaman di Subak Sangeh bercampur antara wanita dan pria dengan sistem upah borongan per hektar sehingga upah kerja pria dan wanita sama. Salah satu kendala yang dihadapi dalam menerapkan cara tanam jajar legowo adalah sulitnya menemukan buruh wanita yang mau dan mampu melakukan jajar legowo

d) Penyiangan

Penyiangan gulma dalam usahatani padi di Subak Sangeh dikenal dengan istilah (Mejukut). Mejukut merupakan kegiatan mencabut rumput-rumput liar yang terdapat di sela-sela tanaman padi. Namun untuk mempermudah pengerjaannya, kebanyakan petani hanya melakukan proses pencabutan gulma dengan Mejukut sekali saja. Pada tahapan kedua pembersihan gulma dilakukan dengan menggunakan herbisida. Disamping prosesnya sangat mudah dan cepat, penggunaan herbisida dapat menekan biaya produksi khususnya di upah tenaga kerja dalam keluarga.

e) Pemupukan
Aturan pemupukan yang diberikan dalam Program Upsus adalah melakukan pemupukan sebanyak tiga kali dengan komposisi pupuk yang seimbang. Sebagian besar petani dalam menerapkan Program Upsus telah mengikuti anjuran jumlah pemupukan yang harus dilakukan, yakni sebanyak 3 kali. Dalam hal penambahan penggunaan pupuk kandang, ada yang dikeluhkan petani yaitu meningkatnya biaya produksi untuk membeli pupuk kandang.

\section{f) Penyemprotan}

Pembasmian hama dan pengendalian gulma biasanya dilakukan dengan melakukan penyemprotan secara berkala. Penyemprotan ini dilakukan dengan cara yang tepat dan dosis yang sesuai. Petani di Subak Sangeh melakukan penyemprotan pertama dengan menggunakan ALI. ALI berfungsi untuk membunuh rumput liar yang tumbuh pasca pengolahan tanah. Setelah tanaman padi berumur 42 hari penyemprotan dilakukan dengan menggunakan Score yang bertujuan untuk membasmi hama yang ada di padi, seperti belalang, ulat dan sebagainya. Obat yang digunakan sebagian besar masih berupa obat-obatan kimiawi baik padat maupun cair. Penyemprotan menggunakan obat organik yang terbuat dari bahan-bahan alami tidak dilakukan oleh petani di Subak Sangeh karena dianggap kurang efektif serta memakan waktu yang lebih lama. Dalam melakukan penyemprotan petani langsung melakukan penyemprotan sendiri ke areal sawah tanpa tenaga upahan.

\section{Biaya produksi padi}

Biaya usahatani merupakan biaya yang dikeluarkan untuk memperoleh hasil dari usahatani yang dilakukan oleh petani. Biaya usahatani sangat bergantung pada besar kecilnya skala produksi. Dalam penelitian ini biaya usahatani diklasifikasikan ke dalam biaya variabel dan biaya tetap. Biaya variabel meliputi biaya bibit, pengolahan tanah, pupuk, pestisida dan upah tenaga kerja. Berikut merupakan biaya yang dikeluarkan petani padi dalam memproduksi padi selama satu musim tanam. Rata-rata biaya usahatani padi dapat dilihat pada Tabel 4.1. 
Table 4. Rata-rata biaya usahatani padi per hektar per musim tanam yang dikeluarkan petani di Subak Sangeh

\begin{tabular}{lll}
\hline Uraian & & Biaya Variabel \\
\hline Pengolahan Tanah & & 279.000 \\
Bibit & & 1.500 .000 \\
Penanaman & & 1.440 .873 \\
Pupuk & Pengairan & 274.054 \\
Pestisida & Persemaian & 821.283 \\
HOK & Penyiangan & 69.594 \\
& Penyemprotan & 635.135 \\
& Pemupukan & 92.905 \\
& & 194.810 \\
\hline Total VC & & 7.107 .810 \\
Penyusutan Alat & Sabit & 26.154 \\
& Cangkul & 19.026 \\
Total VC & Sprayer & 76.282 \\
Total Biaya & & 121.462 \\
\hline Subi Diana & & 7.229 .116 \\
\hline
\end{tabular}

Sumber: Diolah dari data primer

Biaya pengolahan tanah menggunakan sistem borongan dengan satuan luas yang dihitung per are. Jadi biaya untuk pengolahan tanah dalam usahatani padi di Subak Sangeh sebesar Rp 1.800.000/ha/mt. Bibit merupakan salah satu faktor produksi dalam usahatani padi dan sangat mempengaruhi terhadap pencapaian hasil yang maksimal. Benih yang dipakai oleh petani padi Subak Sangeh adalah benih varietas Ipari dan Sibagendit. Sebelum program petani menggunakan bibit sebanyak $30 \mathrm{Kg} / \mathrm{Ha} / \mathrm{Mt}$, sedangkan setelah program petani menggunakan bibit rata-rata $18,6 \mathrm{~kg} / \mathrm{ha} / \mathrm{mt}$. Jadi dalam penerapan Program Upsus biaya untuk membeli bibit sebesar Rp 279.000/ha/mt lebih rendah dari sebelum penerapan Program Upsus sebesar Rp 360.000/ha/mt.

Penanaman merupakan suatu kegiatan pemindahan bibit padi dari tempat pembenihan ke lahan sawah. Petani di Subak Sangeh melakukan penanaman dengan bantuan tenaga kerja upahan yang menggunakan sistem borongan. Dalam penerapan Program Upsus biaya penanaman padi sebesar Rp1.500.000/ha/mt. Penggunaan pupuk bertujuan untuk memenuhi kebutuhan akan hara mineral bagi tanaman yang tidak sepenuhnya dapat disediakan oleh tanah. Dalam menerapkan Program Upsus biaya untuk pembelian pupuk sebesar Rp 1.440.873/ha/mt. Mengantisipasi dan mengendalikan serangan hama dan penyakit tanaman padi, petani di Subak Sangeh menggunakan pestisida kimia seperti Ally, Virtaco, Score, Sidametrin dan Pastak, jenis obat tersebut petani kombinasikan sesuai keadaan padi di sawah. Pada proses pengendalian hama biaya yang dikeluarkan petani sebesar Rp 274.054/ha/mt. Penggunaan pestisida dalam pengendalian hama dapat menekan kerusakan padi sehingga kesehatan tanaman dapat terjaga dan mampu berproduksi secara optimal.

Tenaga kerja luar keluarga dalam penerapan Program Upsus diupah secara borongan sehingga tidak dihitung dengan HOK. Secara keseluruhan total biaya variabel yang dibayarkan petani padi di Subak Sangeh setelah menerapkan Program Upsus sebesar Rp 7.107.654/ha/mt. Secara keseluruhan total biaya usahatani padi dalam menerapkan Program Upsus sebesar Rp 7.229.116/ha/mt.

\section{Penerimaan Usahatani Padi}

Soekartawi (1995), mengemukakan penerimaan usahatani adalah perkalian antara produksi yang diperoleh dengan harga jual. Penerimaan juga merupakan seluruh pemasukan yang diterima dari kegiatan ekonomi yang menghasilkan uang tanpa dikurangi dengan biaya produksi yang dikeluarkan.

Dalam penerapan Program Upsus dengan menerapkan sistem tanam jajar legowo dan penggunaan bibit unggul dapat meningkatkan produksi padi dari 6,19 ton/ha menjadi 8,15 ton/ha. Dengan harga jual gabah kering panen Rp3.800/kg maka penerimaan petani padi di Subak Sangeh dalam menerapkan Program Upsus sebesar Rp $30.970 .000 / \mathrm{ha} / \mathrm{mt}$.

\section{Pendapatan usahatani padi}

Pendapatan merupakan selisih antara penerimaan dengan biaya, hasil penelitian di lapangan menunjukkan bahwa rata-rata produktivitas padi di Subak Sangeh sebesar 8,15ton/ha untuk gabah kering panen dengan harga jual $\mathrm{Rp} 3.800 / \mathrm{kg}$ sehingga total penerimaan petani sebesar $\mathrm{Rp}$ $30.970 .000 / \mathrm{ha} / \mathrm{mt}$. sedangkan biaya yang dikeluarkan untuk kebutuhan input usahatani padi, mulai dari biaya bibit, pengolahan lahan, pupuk, pestisida, dan lain-lain sebesar Rp7.229.116/ha/mt.

Mengacu pada total penerimaan dan total biaya yang dikeluarkan pada kegiatan usahatani padi sawah, maka besarnya pendapatan yang diperoleh petani padi di Subak Sangeh dalam menerapkan Program Upsus sebesar Rp 23.740.884/ha/mt. 


\section{Dampak Program Upsus di Subak Sangeh}

Program Upsus bertujuan untuk meningkatkan produktivitas tanaman padi, dimana saat ini produktivitas padi hanya 4,7ton/ha, setelah diterapkannya Program Upsus diharapkan produktivitas padi dapat meningkat menjadi 6-7 ton/ha. Berkaitan dengan hal tersebut Subak Sangeh telah menerapkan Program Upsus guna meningkatkan produktivitas padi dan diharapkan pula peningkatan produksi mampu meningkatkan pendapatan petani. Pada sub bab berikut akan dijelaskan dampak Program Upsus Padi terhadap produktivitas petani.

\section{Dampak Program Upsus Terhadap Pendapatan} Petani Padi

Pendapatan usahatani dapat digunakan sebagai indikator untuk melihat sejauh mana peranan usahatani padi sawah dan sejauh mana peranan Program Upsus terhadap pendapatan petani di daerah penelitian. Analisis ini terdiri dari struktur biaya dan penerimaan usahatani padi sawah. Selain itu, dengan analisis ini dapat diketahui gambaran usahatani saat ini. Lebih jelasnya pendapatan petani padi di Subak Sangeh dapat dilihat pada Tabel 5.2 dibawah ini.

Tabel 5. Rata-rata Pendapatan, Penerimaan, Biaya, usahatani padi per hektar per musim tanam yang diterima petani di Subak Sangeh

\begin{tabular}{llrrrrr}
\hline No & \multicolumn{1}{c}{ Uraian } & \multicolumn{2}{c}{ Sebelum Upsus } & \multicolumn{2}{c}{ Setelah Upsus } & Dampak (\%) \\
\hline 1 & Biaya & Rp & 6.977 .684 & $\mathrm{Rp}$ & 7.229 .116 & 8,84 \\
2 & Produktivitas & & 6,19 & & 8,15 & 24,05 \\
3 & Penerimaan & $\mathrm{Rp}$ & 23.522 .000 & $\mathrm{Rp}$ & 30.970 .000 & 24,05 \\
4 & Pendapatan & $\mathrm{Rp}$ & 16.544 .316 & $\mathrm{Rp}$ & 23.740 .884 & 30,31 \\
5 & R/C Ratio & & 3,37 & & 4,28 & 21,26 \\
\hline
\end{tabular}

Sumber:Diolah dari data primer

Seperti yang terlih at pada Tabel 5.2 biaya sebelum menjalankan Program Upsus adalah sebesar Rp 6.977.684/ha/mt sedangkan biaya untuk usahatani padi setelah menerapkan Program Upsus adalah Rp $7.229 .116 / \mathrm{ha} / \mathrm{mt}$. Hal ini disebabkan oleh biaya usahatani setelah Program Upsus menggunakan komponen input yang lebih banyak daripada sebelum menerapkan Program Upsus.

Tingginya biaya pada pelaksanaan Program Upsus berdampak terhadap meningkatnya produktivitas padi, dari 6,19 ton/ha menjadi 8,15 ton/ha meningkat $24,05 \%$. Sehingga penerimaan juga ikut meningkat yang diikuti oleh pendapatan petani yang juga meningkat dari Rp16.544.316/ha/mt sebelum menerapkan Program Upsus menjadi Rp23.740.884/ha/mt setelah penerapan Program Upsus atau meningkat sebesar $30,31 \%$. Secara keseluruhan Program Upsus mampu meningkatkan Pendapatan petani, walaupun terjadi peningkatan biaya sebesar $3,48 \%$. Peningkatan produktivitas dan penerimaan juga ikut naik sebesar $24,05 \%$. Hal ini menunjukkan bahwa Program Upsus berhasil dalam penerapannya yang salah satunya bertujuan untuk meningkatkan produksi dan produktivitas petani dalam usahatani padi sawah. Secara teknis usahatani padi sawah yang dilaksanakan pada Program Upsus adalah dengan menerapkan Teknologi Pengelolaan Tanaman Terpadu (PTT) padi sawah. PTT merupakan model dan bukan paket teknologi yang tetap, tetapi merupakan pendekatan usahatani yang dinamis. (Bobihoe, 2007).

Yusuf (2010), menjelaskan bahwa dalam usaha meningkatkan produksi beras untuk pencapaian swasembada pangan, diperlukan upaya terobosan rekayasa teknologi, sosial, ekonomi dan kelembagaan yang dapat diterapkan secepatnya. Salah satu rekayasa teknologi yang dapat diterapkan adalah dengan model Pengelolaan Tanaman Terpadu (PTT) padi.

\section{Dampak upsus terhadap produktivitas padi}

Dampak Upsus terhadap Produktivitas padi di hitung dengan menggunakan analisis uji $t$. dari hasil analisis menunjukkan bahwa nilai t-value lebih besar dari 2,56. Artinya perbedaan nilai sebelum dan setelah menerapkan Program Upsus pada taraf kepercayaan (signifikan) 99\% dapat diterima.

Nilai Signifikan sebesar 0,000 yaitu lebih kecil dari 0,01 artinya terdapat perbedaan produktivitas usahatani padi di Subak Sangeh pada taraf kepercayaan (signifikan) 1\%. Hal ini berarti juga penerapan Program Upsus sangat berpengaruh untuk meningkatkan produktivitas usahatani padi di Subak Sangeh.

Dilihat dari nilai correlation ( $r$ ) dikuadratkan maka akan menunjukkan dampak Program Upsus terhadap peningkatan produktivitas padi di Subak Sangeh, dari hasil analisis menunjukkan nilai $\mathrm{r}^{2}$ adalah 0,55 atau $55 \%$. Hal ini menunjukkan bahwa Program Upsus memberikan dampak terhadap peningkatan produktivitas padi sebesar $55 \%$ dan sisanya disebabkan oleh faktor lain.

\section{Kendala-Kendala Dalam Usahatani Padi di Subak Sangeh}

Dalam melaksanakan kegiatan usahatani padi di Subak Sangeh khususnya dalam menerapkan Program Upsus petani kesulitan dalam pembelian saprodi karena keterbatasan modal Permodalan. Petani belum dapat memahami teknologi dari pengembangan program Upsus secara menyeluruh karena pendidikan petani yang rendah sehingga diperlukan suatu metode pendekatan oleh pihak 
terkait terutama Penyuluh Pertanian Lapangan. Petani di Subak Sangeh belum mampu menerapkan teknologi secara optimal sehingga pemanfaatan tenaga kerja dalam hal irigasi belum berjalan dengan baik karena petani belum mampu memahami dan menerapkan sistem pengairan berselang. Dari segi tenaga kerja petani kesulitan mencari tenaga kerja untuk menanam dengan sistem tanam jajar legowo.

\section{SIMPULAN DAN SARAN}

\section{Simpulan}

Berdasarkan pembahasan pada bab sebelumnya, maka dapat ditarik beberapa kesimpulan yaitu:

1. Biaya usahatani padi di Subak Sangeh dalam menerapkan Program Upsus sebesar Rp 7.229.116/ha/mt. Penerimaan petani di Subak Sangeh sebesar Rp 30.970.000/ha/mt. Jadi pendapatan petani padi di Subak Sangeh dalam menerapkan Program Upsus sebesar Rp 23.740.884/ha/mt, serta nilai R/C Ratio sebesar 4,28 .

2. Program Upsus dapat meningkatnya produktivitas padi sebesar $24,05 \%$. Hal ini mengindikasikan bahwa Program Upsus sangat berpengaruh untuk meningkatkan produktivitas usahatani padi di Subak Sangeh.

3. Kendala-kendala yang dihadapi petani di Subak Sangeh secara umum yaitu masalah dalam kebutuhan sarana produksi seperti pupuk, serta belum mampunya petani dalam mengadopsi inovasi teknologi secara utuh untuk meningkatkan produktivitas.

\section{Saran}

Berdasarkan uraian kesimpulan dan analisis tersebut maka yang dapat direkomendasikan sebagai saran yaitu:

1. Agar menghasilkan pendapatan yang lebih besar, petani setidaknya mengurangi jumlah biaya produksi. Biaya produksi yang dimaksud adalah biaya membayar upah tenaga kerja, jika proses produksi dapat dilakukan sendiri atau mengandalkan tenaga kerja keluarga maka pendapatan pun akan naik karena berkurangnya biaya produksi yang dikeluarkan.

2. Keterbukaan dan kemampuan petani dalam menerima atau mengadopsi inovasi teknologi di bidang pertanian harus terus ditingkatkan agar mampu menerapkan program atau cara berusahatani yang baik guna meningkatkan produktivitas tanaman padi.

3. Peran petugas penyuluh lapangan (PPL) atau dinas terkait agar terus diintensifkan guna memberikan pengarahan, penyuluhan, pelatihan terkait dengan usahatani padi dalam menerapkan Program Upsus dan penentuan waktu tanam.

\section{UCAPAN TERIMA KASIH}

Melalui e-jurnal ini saya menyampaikan ucapan terima kasih yang tulus kepada pengurus dan anggota subak yang terlibat dengan penuh perhatian dan memberikan dukungan berupa informasi dan pengalaman, sehingga saya dapat menyelesaikan ejurnal ini dengan baik.

\section{DAFTAR PUSTAKA}

Arikunto, Suharsimi dan Cepi Safrudin Abdul Jabar. (2009). Evaluasi Program Pendidika. Bumi Aksara.Jakarta.

A.T. Mosher, 1968. Menggerakkan dan Membangun Pertanian, Jakarta : Jayaguna.

BPS Provinsi Bali. 2010. Bali dalam angka 2010.

Bobihoe, 2007. Buku Saku Pengelolaan Tanaman Terpadu (PTT) Padi Sawah. Inovasi Teknologi Untuk Meningkatkan Produktivitas Tanaman Padi. Litbang Pertanian. Jambi: BPTP.

Gulo, W. 2000. Metodologi Penelitian. Grasindo. Jakarta.

Khomsam, Ali. 2003. Pangan dan Gizi. PT Raja Grafindo Persada. Jakarta.

Kuncoro, M. 2003. Metode Riset untuk Bisnis dan Ekonomi. Bagaimana meneliti dan menulis tesis. PT. Gelora Aksara Pratama : Erlangga.

Singaribum, M dan S Effendi. 1989. Metode Penelitian Survey. LP3ES. Jakarta.

Soekartawi. 1995.Analisis Usahatani. Universitas Indonesia (UI-Press). Jakarta.

Yusuf, 2010. Teknologi Budidaya Padi Sawah Mendukung SL-PTT di Sumatera Utara. Medan: Balai Pengkajian Teknologi Pertanian Sumatera Utara. 